\title{
KARAKTERISTIK FESES AYAM KAMPUNG SUPER YANG DIBERI KUNYIT
}

\author{
Characteristics of Super Kampung Chicken Feces that Given Turmeric Flour \\ Fahria Datau*, Ferdi Wahyudi, dan Safriyanto Dako \\ Jurusan Peternakan Fakultas Pertanian Universitas Negeri Gorontalo \\ *Corresponding Author: email: fahriadatau63@gmail.com,
}

\begin{abstract}
The purpose of this study was to determine how the use of turmeric in chicken feed super against the characteristics of the resulting feces. A total of 120 Super Kampung Chickens were used in this study. The treatment period was carried out from day 17 to day 60 . The cage used is personal, the size of the cage is $100 \mathrm{~cm} \times 100 \mathrm{~cm}$, as many as 20 units, and each cage. A completely randomized design (CRD) was used with 5 treatments and 4 replications in this study. The provision of turmeric flour in super chicken feed without turmeric (P0) showed that the feces produced were predominantly solid-liquid textured, with brownish-white stool color and a very strong odor. While the feed and turmeric flour were up to $6 \%$, the texture of the dominant stool was solid, the color of the stool was brown, slightly white, black, with a non-pungent odor. There was a decrease in fecal $\mathrm{pH}$ ranging from 6.60 (without turmeric) to 5.61 (given turmeric). The weight of the feces for each treatment is the same. Giving turmeric flour up to $6 \%$ in feed ingredients can reduce the $\mathrm{pH}$ of the feces, and improve the visual characteristics of Kampung Super chicken feces.
\end{abstract}

Keywords: Feces, Kampung Super Chicken, pH, turmeric flour

\begin{abstract}
ABSTRAK
Tujuan penelitian ini adalah untuk mengetahui penggunan kunyit dalam pakan ayam kampung super terhadap karateristik feses yang dihasilkan. Sebanyak 120 ekor Ayam Kampung Super digunakan dalam penelitian ini. Periode perlakuan dilakukan pada hari ke-17 sampai hari ke-60. Kandang yang digunakan adalah personal cage, ukuran kandang $100 \mathrm{~cm} \times 100 \mathrm{~cm}$, sebanyak 20 unit dan masing masing cage. Penelitian ini menggunakan Rancangan Acak Lengkap (RAL) dengan 5 perlakuan dan 4 ulangan. Pakan yang diberikan adalah pakan ayam kampung super tanpa kunyit (P0) menunjukan feses yang dihasilkan dominan bertekstur padat-cair, dengan warna feses putih kecoklatan dan bau yang sangat menyengat. Sedangkan pemberian pakan dengan tepung kuyit hingga $6 \%$, tekstur feses dominan padat, warna feses coklat sedikit putih, hitam, dengan bau yang tidak menyengat. Terjadi penurunan pH feses berkisar 6.60 ( tanpa kunyit) menjadi 5.61 (diberi kunyit). Bobot feses setiap perlakuan adalah tidak berbeda nyata $(\mathrm{P}>0.05)$. Pemberian tepung kunyit hingga $6 \%$ dalam bahan pakan mampu menurunkan $\mathrm{pH}$ feses, dan memperbaiki karakteristik visual feses ayam Kampung Super
\end{abstract}

Kata Kunci : Ayam kampung super, feses, pH, Tepung kunyit, Science, 3(1), 31-37 


\section{PENDAHULUAN}

Usaha peternakan di Indonesia terus berkembang ditandai dengan peningkatan jumlah ternak dan kualitas produjsi ternak, baik peternakan modern maupun peternakan secara tradisional. Keadaan ini didorong adanya kesadaran masyarakat akan kebutuhan gizi yang bersumber dari hewani, salah satunya adalah perternakan ayam Kampung super. Ayam kampung super adalah ayam hasil silangan tersebut, sehingga ayam ini memiliki pertumbuhannya lebih cepat dibanding ayam lokal (Yaman, 2010), dan termasuk golongan ayam bukan ras atau ayam buras yang merupakan persilangan antara ayam lokal jantan dengan ayam ras betina (Dako, dkk., 2019). Variasi warna bulu di keturunan F1 dominan columbian (Dako, et al 2020), dan heterosigositas yang terbentuk sebesar $0.688 \pm 0.121$ (Saleh, U, dkk 2020). Selain itu ayam kampung super juga memiliki masa pemeliharaan yang pendek dengan kualitas karkas yang baik dibandingkan dengan ayam kampung lokal. Bobot hidup ayam kampung super yaitu 850,75 gr/ekor saat panen (Sigaha, dkk. 2019).

Menurut Muis, M., \& Warisman, B. K. (2020) Usaha ternak ayam kampung super memiliki nilai nilai $\mathrm{R} / \mathrm{C}$ Ratio 1.95 nilai BEP per unit $15.60 / \mathrm{kg}$, sehingga banyak peternak yang berusaha komoditas ayam ini terutama peternak lokal. Namun terkadang usaha peternakan unggas di tuding sebagai usaha yang ikut mencemari lingkungan. Menurut Peraturan Menteri melalui SK Mentan No. 237 tahun 1991 dan SK Mentan 752 tahun 1994, menyatakan bahwa usaha peternakan dengan populasi tertentu perlu dilengkapi dengan upaya pengelolaan dan pemantauan lingkungan. (Jayanti, dkk., 2015). Pencemaran udara diartikan sebagai adanya bahan-bahan atau zat asing di dalam udara yang menyebabkan perubahan susunan (komposisi) dari keadaan normalnya. Keberadaan bahan atau zat asing di dalam udara dalam jumlah tertentu serta berada di udara dalam waktu yang cukup lama, akan dapat mengganggu kehidupan manusia, hewan dan binatang (Wardhana, 2004 dalam Jayanti, dkk., 2015).

Feses unggas merupakan poduk akhir dari proses pencernaan pakan dan air yang di konsumsi oleh seekor ternak, dalam bentuk cair dan padat. Feses ayam kampung super yang dibuang memiliki kandungan NH3 (amoniak), yang menjadi sumber bau. Amonia adala gas hasil dekomposisi limbah nitrogen dalam eskreta, seperti uric acid, protein yang tidak dapat diserap secara sempurna, asam amino dan senyawa non protein nitrogen (NPN) lainnya akibat adanya aktivi-tas mikroorganisme didalam feses (Manin et al., 2010). Kandugan amoniak NH3) erat hubungannya dengan efisiensi penyerapan zat makanan khususnya protein dan asam amino. Protein tidak terserap oleh alat pencernaan maka akan dikonversi menjadi urine acid dan di ekskresikan bersama feses. Keberadaan banyaknya bakteri ulicolytik dan bakteri anaerobic dalam urin berakibat proses dekomposisi dalam urine acid terjadi cepat yang menghasilkan amoniak (NH3) (Hendalia,dkk, 2012). Feses ini Jika tidak dikelola dengan baik maka akan menimbulkan permasalahan baru dilingkungan sekitar. Penanganan amoniak dalam feses sudah banyak cara dilakukan terutama melakukan pengaturan sirkulasi udara dam kandang, dan menempatkan areal kandang yang jauh dari pemukiman, diharapkan dapat meminimalisasi pencemaran udara. Tingginya amoniak dalam feses diakibatkan oleh sistim pencernaan yang tidak sempurna pada unggas, sehingga protein tidak terserap sempurna oleh tubuh ternak.

Menurut Herry (2010) kunyit mempunyai kadar air $60 \%$, protein $8 \%$, karbohidrat $63 \%$, serat kasar $7 \%$, bahan mineral $4 \%$. Kunyit juga merupakan tanaman berkhasiat obat, yang disebut kurkuminoid yang terdiri dari kurkumin, desmetoksikumin dan bisdesmetoksi 
kurkumin dan lemak, protein, kalsium, fosfor dan besi (Shan, C. Y., \& Iskandar, Y., 2018). Kandungan kurkuminoid terdiri atas senyawa kurkumin dan keturunannya yang mempunyai aktifitas biologis bersepektum luas di antaranya antibakteri, antioksidan, dan antihepatotoksi (Wahyuningtyas, S. E. P, 2017). Bahkan kunyit sebagai jamu dan obat tradisional dapat mengatasi berbagai jenis penyakit, menurunkan kadar lemak, kolesterol dalam darah dan hati, antimikroba, antiseptic, anti inflamasi dan mengurangi bau, (Hartati \& Balittro, 2013)., sedangkan penggunaan kunyit dalam meningkatkan perforama ayam broiler (Pranata, I. P, 2019) dan Ayam petelur (Rofiqoh, W. A. (2019) di laporkan tidak berpengaruh terhadap kemampuan produktifitas. Kajian penggunaan kunyit sebagai pengendali amoniak melalui pemberian kunyit belum banyak diketahui manfaatnya, sehingga kajian ini penting untuk langkah awal dalam mempelajari Karateristik feses unggas yang dihasilkan sebagai akibat pemberian kunyit, sebagai upaya menurunkan amoniak feses. Tujuan penelitian ini adalah untuk mengetahui bagaimana penggunan kunyit dalam pakan ayam kampung super terhadap karateristik Feses yang dihasilkan

\section{METEDOLOGI PENELITIAN}

Penelitian ini telah dilaksanakan

di bulan Juli sampai Agustus 2020 bertempat di Unit Produksi Unggas Jurusan Peternakan Fakultas Pertanian Universitas Negeri Gorontalo. Sebanyak 120 ekor Ayam Kampung Super digunakan dalam penelitian ini. Periode perlakuan dilakukan pada hari ke-17 sampai hari ke-60. Bahan yang digunakan yaitu kunyit yang di parut lalu di jemur dibuat dalam bentuk tepung. Kandang yang digunakan adalah personal cage, ukuran kandang $100 \mathrm{~cm} \times 100 \mathrm{~cm}$, sebanyak 20 unit dan masing masing cage. Ransum yang digunakan adalah Pakan komersial BR1 CP-11 fase starter dan komersial BR2 CP-12 fase finisher.
Adapun perlakuan yang diterapkan adalah :

P0 : Ransum basal tanpa diberi tepung kunyit.

P1 : Ransum basal + tepung kunyit 100 $\mathrm{mg} / \mathrm{kgBB} /$ hari $+100 \mathrm{mg} /$ liter

P2 : Ransum basal + tepung kunyit 200 $\mathrm{mg} / \mathrm{kgBB} / \mathrm{hari}+200 \mathrm{mg} /$ liter

P3 : Ransum basal + tepung kunyit 300 $\mathrm{mg} / \mathrm{kgBB} /$ hari $+300 \mathrm{mg} /$ liter .

P4 : Ransum basal + tepung kunyit 400 $\mathrm{mg} / \mathrm{kgBB} /$ hari $+400 \mathrm{mg} /$ liter .

Rancangan Acak Lengkap (RAL) digunakan dalam penelitian ini terdiri atas 5 perlakuan dan 4 ulangan sehingga terdapat 20 unit percobaan. Setiap ulangan terdiri dari 5 ekor anak ayam DOC, sehingga jumlah ayam kampung super yang digunakan sebanyak 125 ekor. Model matematika rancangan acak lengkap (RAL) seperti yang disarankan oleh Syahruddin., Nahrowi, N., \& Yatno, (2020) adalah:

Keterangan:

$$
Y_{i j}=\mu+t i+e i j
$$

Yi : Hasil pengamatan dari peubah perlakuan kunyit ke-i dengan ulangan kunyit ke-j

$\mu$ : Nilai tengah umum

ti : pengaruh kunyit ke-i

eij : Pengaruh galat percobaan dari perlakuan ke-i dan ulangan ke-j

I : Jumlah perlakuan 1,2,3,4

$\mathrm{J}$ : jumlah ulangan pada perlakuan ke-1,2,3

\section{Prosedur Pembuatan Tepung Kunyit}

Kunyit yang tersedia, dicuci dan dibersihkan dari kotoran yang terdapat atau menempel pada kunyit. Pilihlah kualitas kunyit yang baik. Selanjutnya kunyit di parut menggunkan mesin pemarut. Tepung Kunyit yang sudah digiling halus kemudian di keringkan. Kunyit dalan bentuk halus siap digunakan dengan cara campurkan kedalam pakan. Pemberian pakan menggunkan kunyit dilakukan 2 kali sehari pada pukul 06:00 dan 18:00 dengan jumlah perlakuan. Parameter yang diamati dalam penelitian ini adalah Karateristik Feses, $\mathrm{pH}$ feses dan Bobot Feses. 


\section{Analisis Data}

Data yang diperoleh akan dianalisis dengan menggunakan analisis sidik ragam (ANOVA). Bila terdapat perbedaan nyata dilanjutkan dengan Uji Beda Nyata Terkecil (BNT), khusus untuk Karateistik feses dianalisis secara deskriptif

\section{HASIL DAN PEMBAHASAN}

Tekstur feses Ayam kampung Super

Feses ayam kampung Super merupakan hasil akhir dari proses pencernaan. Tekstur feses kunyit yang diberi kunyit dan tidak diberi kunyit secara visual di gambarkan pada gambar 1 dan 2

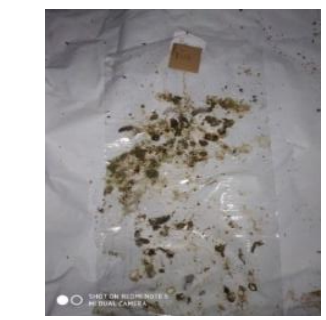

Gambar 1. Tekstur Feses Padat dari ayam diberi kunyit

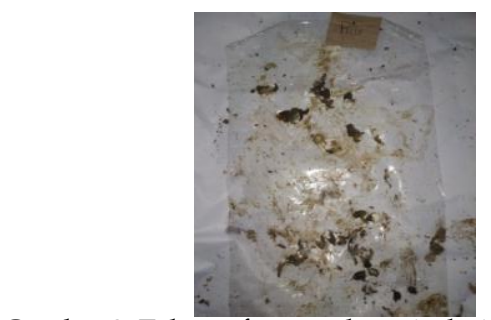

Gambar 2. Tekstur feses padat-cair dari ayam kampung Super tidak diberi kunyit

Hasil penelitian, dengan pemberian tepung kunyit pada pakan ayam kampung super tanpa kunyit (P0) menunjukan feses yang dihasilkan dominan bertekstur padat dan cair, dengan warna feses putih kecoklatan dan bau yang sangat menyengat. Perlakuan $\left(\mathrm{P}_{1}\right)$ dengan $2 \%$ tepung kunyit dominan bertekstur padat, warna feses putih kecoklatan, putih hitam, hitam, putih kehijauan dengan bau yang sedikit menyengat. Perlakuan $\left(\mathrm{P}_{2}\right)$ tekstur feses ayam kampung super dominan bertekstur padat, warna kecoklatan, dengan bau yang tidak terlalu menyengat. Perlakuan $\left(\mathrm{P}_{3}\right)$ dengan pemberian tepung kuyit merubah, tekstur feses ayam kampung super dominan bertekstur padat, dengan warna feses coklat, hitam, dengan bau yang tidak menyengat. Hasil penelitan di perlakuan P3 menunjukkan perubahan tekstur dan warna feses ayam kampung Super, perubahan ini disinyalir adanya penyerapan yang sempurna terhadap protein sehingga komposisi kotoran menjadi padat dan kurang dihinggapi lalat.

Penambahan tepung kunyit (Curcuma domestica) dalam ransum berpengaruh nyata terhadap daya cerna protein, tetapi tidak berpengaruh nyata terhadap daya cerna bahan kering pada ayam pedaging (Pujianti, A., 2013)

Menurut Pertiwi (2017) Pemberian kunyit mengakibatkan penurunan bobot relatif usus halus dan sekum ayam broiler atau ayam kampung sehingga menjadikan feses yang semula cair berubah menjadi padat., dan pemberian kunyit meningkatkan efisiensi penggunaan pakan (Sinurat et al. 2009).

\section{pH feses Ayam Kampung Super}

$\mathrm{pH}$ merupakan keberadaan asam atau basa dari feses unggas. Berdasarkan hasil penelitian $\mathrm{pH}$ feses ayam kampung Super yang dihasilakan dari pemberian tepung kunyit berbeda didalm pakan disajikan dalam grafik 1.

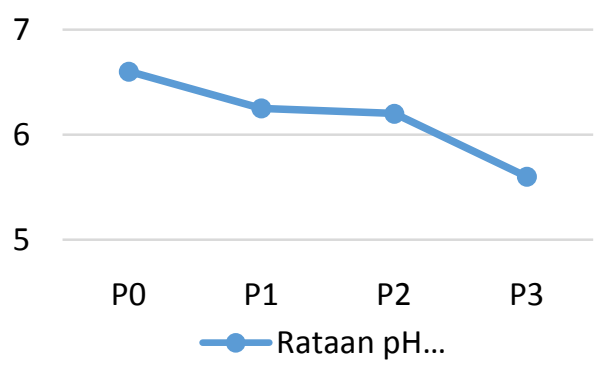

Gambar 3. Grafik pH dari feses ayam Kampung Super

Hasil penelitian menunjukkan terjadi penurunan $\mathrm{pH}$ feses ayam kampung Super yang diberi kunyit dibanding yan tidak diberi kunyit. Penurunan $\mathrm{pH}$ terjadi pada setiap perlakuan, kecuali control. Pada perlakuan P0 menunjukan nilai rataan dengan kadar $\mathrm{pH}$ 6,60, perlakuan $\mathrm{P} 1$ 
menunjukan nilai rataan dengan kadar pH 6,25, perlakuan P2 menunjukan nilai rataaan dengan kadar $\mathrm{pH} \quad 6,20$ dan perlakuan P3 menunjukkan nilai rataan dengan kadar $\mathrm{pH} 5,61$. Hal ini disebabkan oleh pemberian tepung kunyit yang ditambahkan pada pakan ayam lebih efektif dan mengurangi amonia didalam feses sehingga terjadi penurunan $\mathrm{pH}$. Hal ini sesuai dengan penelitian Natsir, dkk (2016) menunjukkan bahwa campuran tepung kunyit dan jahe dalam bentuk tanpa enkapsulasi dan dengan enkapsulasi menunjukkan perbedaan yang sangat nyata $(\mathrm{P}<0,01)$ terhadap $\mathrm{pH}$. Ikhwan, dkk (2016) menyatakan bahwa kadar amonia feses ayam pedaging perlakuan BIS terfermentasi $8 \%$ pada inkubasi 24 dan 48 jam Penurunan kadar amonia pada feses ayam pedaging pada perlakuan isolat bakteri dan BIS menunjukan bahwa, hasil fermentasi isolat bakteri dan BIS dapat menghambat pembentukan ammonia pada feses ayam pedaging.

\section{Bobot Feses}

Rataan bobot feses ayam Kampung Super hasil penelitian disasikan dalam gambar 4.

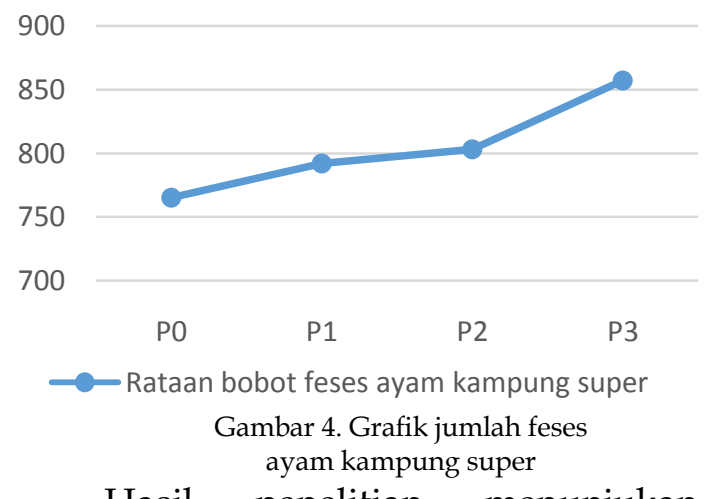
setiap perlakuan memiliki jumlah rataan feses yang dihasilkan. Perlakuan P0 (tanpa tepung kunyit) menunjukan rataan nilai bobot feses ayam kampung super selama periode penelotoan sebanyak 765,25 , perlakuan P1 (tepung kunyit 2\%) menunjukan rataan nilai bobot feses ayam kampung super sebanyak 792,05, perlakuan P2 (tepung kunyit 4\%) menunjukan rataan nilai bobot feses ayam kampung super sebanyak 803,15, dan perlakuan P3 (tepung kunyit 6\%) menunjukan rataan nilai bobot feses ayam kampung super sebanyak 857,3. Hasil analisis statistik (ANOVA) menunjukkan bahwa pengaruh kunyit terhadap berat kotoran ayam kampung super tidak berbeda nyata atau dengan kata lain bahwa penambahan tepung kunyit pada level $2 \%, 4 \%$, dan $6 \%$ pengaruhnya tidak nyata terhadap berat kotoran ayam kampung super. Tidak adanya pengaruh perlakuan terhadap berat kotoran ayam kampung super dikarenakan ternak unggas memiliki pencernaan yang sederhana sehingga feses yang dikeluarkan tetap sama ini sesuai dengan pendapat Pujianti, dkk (2013), Unggas memiliki pencernaan yang sederhana, yaitu hanya tersedia tempat yang sempit untuk kehidupan jasad renik dalam usus yang diperlukan untuk membantu pencernaan pakan. Oleh karena kesederhanaan sifat anatomi dan fisiologi saluran pencernaan, maka ternak unggas banyak bergantung pada enzim yang dikeluarkan oleh sistem pencernaan untuk memecah dan melumat pakan agar mudah diserap oleh tubuh. Bila ransum tidak dapat dicerna dengan enzim yang dihasilkan, maka pakan tersebut tidak banyak berfaedah bagi tubuh.

\section{KESIMPULAN}

Pemberian tepung kunyit hingga 6 $\%$ dalam ransum menggambarkan karateristik visual feses lebih padat, dan terjadinya penurunan $\mathrm{pH}$ feses ayam Kampung Super dan tidak mempengaruhi jumlah feses yang dihasilkan

\section{UCAPAN TERIMA KASIH}

Disampaikan kepada Fakultas Pertanian, Universitas Negeri Gorontalo atas bantuan dalam pendanaaan penelitian ini, melalui Dana PNBP FAPERTA UNG dalam skim Penelitian Kolaboratif 


\section{DAFTAR PUSTAKA}

Shan, C. Y., \& Iskandar, Y. (2018). Studi kandungan kimia dan aktivitas farmakologi tanaman kunyit (Curcuma longa L.). Farmaka, 16(2).

Dako, S. (2019). Crossbreding Between Native Chiken And Leghorn Chiken Strain Isa Brown. Jurnal Peternakan, 16(1), 1-9.

Dako, S., Ilham, F., Laya, N. K., \& Yusuf, F. M. (2020). Nheritance of external genetic characteristics in chicken through triple crossing model. International Journal of Advanced Science and Technology, 29(9 Special Issue)

Ikhwan, R, Rukmini, M.I., dan Pujiyanto, S. 2016. Penurunan Kadar Amonia Feses Ayam Pedaging Menggunakan Prebiotik Bungkil Inti Sawit Dengan Inokulan Bakteri Lactobacillus acigophilus, Lactobacilus bulgaricus dan Bacilus cereus. Jurnal Akademika Biologi, 5 (3), 1-6

Hendalia, E., Manin, F., Yusrizal, Y., \& Nasution, G. M. (2012). Aplikasi probiotik untuk meningkatkan efisiensi penggunaan protein dan menurunkan emisi amonia pada ayam broiler. Agrinak, 2(1), 29-35.

Manin, F., Hendalia, E., \& Yusrizal, Y. (2010). Penggunaan Simbiotik yang Berasal dari Bungkil Inti Sawit dan Bakteri Asam Laktat Terhadap Performans, Lingkungan dan Status Kesehatan Ayam Broiler. Laporan Penelitian Strategi Nasional. Jambi (ID): Universitas Jambi

Masili, S., Dako, S., Ilham, F., \& Gubali, I. S. (2018). Heritabilitas Bobot Telur, Bobot Tetas Dan Bobot Badan Ayam Hasil Persilangan Umur 1
Minggu (DOC). Jambura Journal of Animal Science, 1(1), 1-5.

Muis, M., \& Warisman, B. K. (2020). Analisis Usaha Ayam Kampung Super Dengan Pemberian Ekstrak Kunyit Dan Mengkudu. Jurnal Agrisistem: Seri Sosek dan Penyuluhan, 16(1), 1-5.

Natsir Halim Muhammad, Widodo Eko, Murharlien 2016. Penggunaan Kombinasi Tepung Kunyit (Curcuma Domestica) Dan Jahe (ZingiberOfficinale) Bentuk Enkapsulasi Dan Tanpa Enkapsulasi Terhadap Karakteristik Usus Dan Mikroflora Usus Ayam Pedaging. Department of Animal Production, Faculty of Animal Husbandry, Brawijaya University, Malang. Malang. Vol. 40

Pranata, I. P., Astawa, I. P., \& Mahardika, I. G. (2019). Pengaruh Pemberian Bubuk Kunyit (Curcumalonga) pada Air Minum terhadap Performa Ayam Broiler. Jurnal Peternakan Tropika, 7(2), 881-890.

Pertiwi, D. D. R., Murwani, R., \& Yudiarti, T. (2017). Bobot Relatif Saluran Pencernaan Ayam Broiler Yang Diberi Tambahan Air Rebusan Kunyit Dalam Air Minum. Jurnal Peternakan Indonesia (Indonesian Journal of Animal Science), 19(2), 6165.

Pujianti, A., Jaelani, A., \& Widaningsih, N. (2013). 7. Penambahan Tepung Kunyit (Curcuma domestica) Dalam ransum Terhadap Daya Cerna Protein dan Bahan Kering Pada Ayam Pedaging. Ziraa'ah Majalah Ilmiah Pertanian, 36(1), 4959.

Rofiqoh, W. A. (2019). Pengaruh Penambahan Tepung Kunyit (Curcuma Domestica Val.) Dan Lisin 
Dalam Pakan Terhadap Penampilan Produksi Ayam Petelur (Doctoral dissertation, Universitas Brawijaya).

Sigaha, F., Saleh, E. J., \& Zainudin, S. (2019). Evaluasi Persentase Karkas Ayam Kampung Super Dengan Pemberian Jermai Jagung Fermentasi. Jambura Journal of Animal Science, 2(1), 1-7.

Sinurat, A. P., Purwadaria, T., Bintang, I. A. K., Ketaren, P. P., Bermawie, N., Raharjo, M., \& Rizal, M. (2009). Pemanfatan Kunyit Dan Temulawak Sebagai Imbuhan Pakan Untuk Ayam Broiler. JITV, 14(2), 90-96.

Syahruddin, S., Nahrowi, N., \& Yatno, Y. (2020). Kemampuan Polisakarida Mannan Sebagai Oral Adjuvan Vaksin Avian Influenza Pada Ayam Broiler. Jambura Journal of Animal Science, 2(2), 90-101.

Saleh, U. (2020). Keseimbangan Genetik Eksternal pada Ayam Hasil Silangan. Jambura Journal of Animal Science, 2(2), 76-89.

Wahyuningtyas, S. E. P., Permana, D. G. M., \& Wiadnyani, A. A. I. S. (2017). Pengaruh Jenis Pelarut Terhadap Kandungan Senyawa Kurkumin dan Aktivitas Antioksidan Ekstrak Kunyit (Curcuma domestica Val.). Jurnal ITEPA Vol, 6(2). 